The Philosopbical Journal of Conflict and Violence

Vol. III, Issue 2/2019

(C) The Authors 2019

Available online at http://trivent-publishing.eu/

\title{
Who Guards the Guardians? Kant, Hamann, and the Violence of Public Reasoners
}

\author{
Charles M. Djordjevic \\ Institute for Philosophy, University of Zurich, Switzerland, \\ charles.djordjevic@philos.uzh.ch
}

\begin{abstract}
This paper examines one of the most potent contemporaneous criticisms of the German Enlightenment (circa 1790) as well as the lessons that can be learned from such criticism. Specifically, it examines Kant's famous essay, "An Answer to the Question: What is Enlightenment," and Hamman's objection drawn mainly from his "Letter to Christian Jacob Kraus." It further argues Hamann's criticisms are foresighted, especially when read against the subsequent dark imperil history of the 'West' as seen in post-colonial theory.
\end{abstract}

Keywords: Kant; Hamann; Enlightenment; Public reason; Violence; Centralization; Postcolonial thought.

DOI: 10.22618/TP.PJCV.20204.1.201002

The PJCV Journal is published by Trivent Publishing

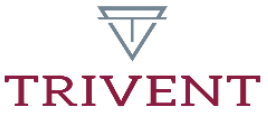

This is an Open Access article distributed in accordance with the Creative Commons Attribution Non Commercial (CC$B Y-N C$-ND 4.0) license, which permits others to copy or share the article, provided original work is properly cited and that this is not done for commercial purposes. Users may not remix, transform, or build upon the material and may not distribute the modified material (bttp:/ / creativecommons.org/ licenses/by-nc/4.0/) 


\title{
Who Guards the Guardians? Kant, Hamann, and the Violence of Public Reasoners
}

\author{
Charles M. Djordjevic \\ Institute for Philosophy, University of Zurich, Switzerland, \\ charles.djordjevic@philos.uzh.ch
}

\begin{abstract}
This paper examines one of the most potent contemporaneous criticisms of the German Enlightenment (circa 1790) as well as the lessons that can be learned from such criticism. Specifically, it examines Kant's famous essay, "An Answer to the Question: What is Enlightenment," and Hamman's objection drawn mainly from his "Letter to Christian Jacob Kraus." It further argues Hamann's criticisms are foresighted, especially when read against the subsequent dark imperil history of the 'West' as seen in post-colonial theory.
\end{abstract}

Keywords: Kant; Hamann; Enlightenment; Public reason; Violence; Centralization; Postcolonial thought

\section{Introduction}

One of the most powerful, and multifaceted, contemporaneous attacks on the German Enlightenment (circa 1790) can be found in Hamann's Letter to Christian Jacob Kraus concerning Kant's essay An Answer to the Question: What is Enlightenment ${ }^{1}$ (and related texts). In this letter, Hamann takes Kant to task for, among other things, his sexism ${ }^{2}$, his chiliasm ${ }^{3}$, and his view of human nature and freedom. ${ }^{4}$ However, I focus on one strand in Hamann's letter that presages many of the violent and imperialistic excesses that were later undertaken in the name of the so-called Enlightenment. Specifically, I isolate, reconstruct, and defend Hamann's contention that the Enlightenment project conceptually depends on an asymmetric and unstable power relation between "guardians" and "herd" that can only be maintained by violence.

\footnotetext{
${ }^{1}$ Immanuel Kant, "An Answer to the Question: What is Enlightenment?," in What is Enlightenment? Eighteenth-Century Answers and Twentieth-Century Questions, ed. James Schmidt (Berkeley: University of California Press, 1996), 58-63 ; Johann Georg Hamann, "Letter to Christian Jacob Krauss," in What is Enlightenment? Eighteenth-Century Answers and Twentieth-Century Questions, 145-148.

2 E.g., Immanuel Kant, Toward Perpetual Peace and Other Writings on Politics, Peace, and History, ed. Pauline Kleingeld (New Haven: Yale University Press, 2006), 49; Johann Georg Hamann "Letter to Christian Jacob Krauss," 148.

${ }^{3}$ E.g., Immanuel Kant, Toward Perpetual Peace and Other Writings on Politics, Peace, and History, ed. P. Kleingeld (New Haven, CT: Yale University Press, 2006), 150-162; Johann Georg Hamann, "Letter to Christian Jacob Krauss," in What is Enlightenment? Eighteenth-Century Answers and Twentieth-Century Questions, 146.

${ }^{4}$ E.g., Immanuel Kant, Groundwork of the Metaphysics of Morals (New Haven, CT: Yale University Press, 2002), 62-69; Johann Georg Hamann, "Letter to Christian Jacob Krauss," 147
} 
Section one sets the stage; I offer a close reading of Kant's An Answer to the Question: What is Enlightenment. I focus specifically, on the relationship between public reasoning, those who can write, and the political powers that be. In section two, I isolate the thread of Hamann's critique that interests me and reconstruct it in a more "conventional" philosophical manner. In section three, I argue that Hamann's criticism and much post-colonial theory align in a telling way.

I should note here that since my main interest is on Kant's What is the Enlightenment essay and Hamann's reply, I use references to other works sparingly and solely to fill out otherwise opaque arguments. I should also note that my reading of Kant is decidedly one-sided. This is precisely because my reading is meant to set the stage of Hamann's criticism, and Hamann's reading of Kant's essay is rather unforgiving. ${ }^{5}$

\section{Guardians, Public Reasoning, and Well-Disciplined Armies}

Kant's essay An Answer to the Question: What is Enlightenment is a clear example of non-ideal political theorizing. ${ }^{6}$ By "non-ideal political theory" I mean political theory that begins not from idealized thought experiments, such as the state of nature or the veil of ignorance, but instead from actual (contingent and historically path-dependent) institutions that encode many idiosyncratic and problematic features. ${ }^{7}$ Kant's essay is non-ideal in that Kant claims that "[i]f it is asked "do we live in an enlightened age?" the answer is "No, but we do live in an age of enlightenment."'8 In other words, in an ideal setting, we would live in an enlightened age. However, we do not. Given this, it is incumbent on Kant to tell us what the age of enlightenment is, which political strategies can help develop it further, and what the ideal enlightened end state should be. Let us take each in turn.

To begin, Kant defines enlightenment as "mankind's exit from its self-incurred immaturity." However, "immaturity" is a somewhat problematic translation of the German word "unmündigkeit," which is chiefly a legal and not a psychological term. That being said, translating the word as "minority," though carrying the proper legal connotations, loses both the negative prefix "un" and might elide the specialized use Kant puts it to. Ergo, though slightly ineloquent, I leave the word in the original German. Given this, Kant then defines "unmündigkeit" as the "inability to make use of one's understanding without the guidance of another." $10 \mathrm{He}$ also notes that this sorry state is self-incurred because "its cause lies not in lack of understanding but rather in the lack of resolution and the courage to use it [one's understanding] without the guidance of another." 11 In other words, "[1]aziness and cowardice are the reasons why such a great part of mankind [are in a state of unmündigkeit]." 12 Thus, people are in a state of unmündigkeit, not due to some intrinsic failing or inherent limit, but

\footnotetext{
5 Though see, e.g., Samuel Fleischacker, Kant's Questions: What is Enlightenment (New York, NY: Rutledge Press, 2012), 11-31 \& 133-156, for a more charitable "minimalist" interpretation of Kant's essay.

6 See Robert S. Taylor, "Democratic Transitions and Progress of Absolutism in Kant's Political thought," The Journal of Politics 68/3 (2006): 556-558. Taylor gives an argument about why Kant's "What is Enlightenment?" is best read in this way.

${ }^{7}$ See John Rawls, $A$ Theory of Justice (Cambridge, MA: Harvard University Press, 1999), 132, 214-20, 476, for further comment.

8 Immanuel Kant, "An Answer to the Question: What is Enlightenment?," 62

${ }^{9}$ Ibid., 58.

${ }^{10} \mathrm{Ibid}$.

${ }^{11} \mathrm{Ibid}$

12 Ibid.
} 
instead due to their laziness or cowardice. And the proper remedy is "Sapere aude! Have the courage to use your own understanding!"13

Given this account of both what enlightenment is, and why we have failed to achieve it, Kant then examines three possible strategies that might rectify this situation. The first strategy turns on the individual freeing himself by making use of his own reason. However, Kant dismisses this as his unmündigkeit has become "almost natural to him [a member of the masses]." 14 Indeed, Kant goes so far as to say that many individuals are so "fond of it [their unmündigkeit]... [that they are] truly incapable of making use of his own reason." 15 Moreover, what use of reason individuals do make is done in terms of "[r]ules and formulas... mechanical instruments of a rational use (or rather misuse)... are the fetters of everlasting [unmündigkeit]."16 Thus, "only a few... have managed to free themselves from their unmündigkeit." 17 Thus, Kant is skeptical that an individual member of the herd can simply begin to reason for herself.

The second and third strategy focus not on individuals but the public. Indeed, "that a public should enlighten itself is more likely; indeed, it is nearly inevitable... For there will always be found some who think for themselves, even among the established guardians of the masses, and who... will spread among the herd the spirit of rational assessment of individual worth and the vocation of each man to think for itself." 18 Notice that this accounts for Kant's claim that he, and we, live in an age of enlightenment. In effect, it seems as though there has been some sociological transformation that enables the public to enlighten itself. Indeed, Kant goes so far as to say that the public's self-enlightenment is nearly inevitable. This naturally raises the question of what is unique about our age that makes it an age of enlightenment. To address this, it is best to examine Kant's oddly idiosyncratic use of "public" as it is clear that this "public" is a critical facet of accounting for our age of enlightenment. ${ }^{19}$

To begin, the public cannot simply be an indifferent aggregated sum of individuals. This is partly because, for such a sum, the same fundamental problem raised for the first strategy would reappear. In effect, if individuals are truly incapable of making use of their own understanding because they are so accustomed to their unmündigkeit, then it is unclear why an indifferent aggregate of them would fare better. Instead, what our age is one of enlightenment because, as Kant mentioned, there are established guardians who can shepherd "the herd." Moreover, given Kant's twin claims that the public enlightens itself and that (some) of the guardians enlighten themselves, and then the herd, it is clear that there is a hierarchical relationship between the guardians and the herd that both distinguish this situation from the individual strategy and is required for enlightenment to occur and progress.

Granting this, the question becomes what establishes the public and what maintains this hierarchical relationship that fosters enlightenment? Here, Kant's answer is that "a ruler [or guardian] who, himself enlightened, does not himself fear shadows and at the same time has at hand a large, well-disciplined army that can guarantee public peace can say what a republic

\footnotetext{
13 Ibid., 59.

14 Ibid.

15 Ibid.

16 Ibid.

17 Ibid.

18 Ibid.

19 This point is widely discussed in the secondary literature. For apt discussions, see, e.g., John Christian Laursen, "The Subversive Kant: The Vocabulary of "Public" and "Publicity"," in What is Enlightenment? Eighteenth-Century Answers and Twentieth-Century Questions, 253-267; Robert Louden, "Argue but Obey? Questioning Kant's Enlightenment," in Kant's Shorter Writings: Critical Paths Outside the Critiques, eds. Rafael V. Orden Jiménez, Robert Hanna, Robert Louden, Jacinto Rivera de Rosales, and Nuria Sánchez Madrid (Cambridge, UK: Cambridge Scholars Publishing, 2016), 284-300.
} 
cannot dare: are as much as you what... only obey!" 20 To make sense of this rather jarring claim, consider Kant's claim that

[r]ight is the restriction of the freedom of each to the condition of being compatible with the freedom of all... And public law is the sum of external laws that make such universal harmony possible. Since every limitation of freedom through the will of another is known as coercion, it then follows that the civil constitution is a relation among free human beings who... are nonetheless subject to coercive laws. ${ }^{21}$

Moreover, also note that "[i]f I abstract from all material aspects of public right.... Then I am left with the form of publicity, the possibility of which is implied in any legal claim." 22 And, finally, Kant claims that "[a]ll practical principles of right must contain a strict truth [deduced a priori]... [and] exceptions would nullify the universality [of these rights]." 23 To unpack these claims, and understand their interrelationships, it is vital to notice that, for Kant, a right is logically correlated to a duty such that, for me to have a right to, e.g., use my public reason, requires that some other entity has a duty to ensure that I can exercise this right without hindrance, provided it does not conflict with other people's rights. Given this, for Kant, the entity that bears this duty is the state. Moreover, given this duty, it is clear that the state must be centralized so that it can act as such a guarantor. It is also clear that the state must maintain a monopoly on the legitimate use of violence to secure my right. As Kant said, the state must be capable of restricting individual freedom with coercive and violent force. ${ }^{24}$ Finally, for Kant, rights are necessary correlates of the structure of practical reasoning. To permit any exception or to challenge them in any way is to fall into self-contradiction as the very tools one employs are undermined. In turn, this aligns Kant's account with his day's standard legal definition of "the public" as "in law, properly what belongs to the prince or the higher authorities and not to mere private persons." 25 In effect, the public is precisely a space that is constituted by the state in its role as the enforcer of rights. We shall link this to "public reasoners" in a moment.

With this definition of the public in view, let us return to Kant's enlightenment strategies. The second strategy is revolution. In effect, the herd throws off its yoke, destroys the public by attacking hierarchical relationships, calls into question the role of state violence, and begins to reason for itself. Kant finds this both conceptually incoherent and politically useless. The incoherence is a correlate of how Kant understands the role of the state. In effect, the rights that revolutionaries demand require that the state bear a duty to enforce them. However, the

\footnotetext{
20 Immanuel Kant, “An Answer to the Question: What is Enlightenment?”, 63.

21 Immanuel Kant, "On the Common Saying: This May be True in Theory, but it Does Not hold In Practice, Parts 2 and 3," in Toward Perpetual Peace and Other Writings on Politics, Peace, and History, ed. Pauline Kleingeld (New Haven, CT: Yale University Press, 2006), 45.

22 Immanuel Kant, "Towards Perpetual Peace: A Philosophical Sketch," in Toward Perpetual Peace and Other Writings on Politics, Peace, and History, 104

23 Immanuel Kant, "On the Supposed Right to Lie for Philanthropy," in Kant's Practical Philosophy (Cambridge, UK: Cambridge University Press, 1996), 615.

${ }^{24}$ A similar point is made in Jeremy Waldron, "Kant's Theory of the State," in Toward Perpetual Peace and Other Writings on Politics, Peace, and History, 179-200.

25 Johann Heinrich Zedler, Grosses Vollständiges Universal-Lexikon 1754. Available at: https:/ /www.zedlerlexikon.de $/$ index.html?c $=$ blaettern\&id $=265705 \&$ bandnummer $=29 \&$ seitenzahl $=0577 \&$ supplement $=0$ \&dateiformat $=1 '$ ), (Accessed September 10, 2019).
} 
revolutionaries attack this state, and so its duties, and so the very rights they demand. ${ }^{26}$ Moreover, given that rights are derived from pure practical reason, the assaults of the revolutionaries on the state is self-contradictory as it undermines pure practical reason itself. ${ }^{27}$ Of more interest for our purposes is why Kant claims that the second strategy is useless. He claims that "[a] revolution may perhaps bring about the fall of an autocratic despotism.... But it can never bring about the true reform of a way of thinking. Rather, new prejudices will serve, like the old, as the leading strings of the thoughtless masses." 28 The sort of prejudice at issue is "praejudicium-mutitudinis (for the multitude)- this is peculiar to women and is also quite well suited to them. One who has praejudicium-mutitudinis distrusts his own reason." 29 This is in keeping with his original claim that enlightenment is daring to know. However, it is unclear why revolution engenders new prejudices. To answer this, the key is the thoughtlessness Kant alludes to. As in the first strategy, the critical problem with revolution is that the lazy and cowardly masses are simply incapable of using their reason correctly. In effect, a revolution replaces one boss with another, the cult of religion with the cult of reason, say. It is critical to notice, yet again, that Kant simply assumes that the masses, and the individuals whose aggregate forms it, are incapable of reasoning for themselves. Still, they must be led.

The third strategy is the one Kant endorses. He notes that "a public can achieve enlightenment only gradually." 30 Kant further links this gradual enlightenment to a particular form of negative freedom- specifically freedom of the public to argue and debate about any topic, without fear of censorship or reprisal. Indeed, Kant claims that "[f]or this enlightenment... nothing more is required than freedom... namely the freedom to make a public use of one's reason in all matters." 31 He then defines the public use of reason "[as] that use which anyone makes of it as a scholar before the entire public of the reading world." 32 In other words, for Kant, the reason our age is an age of enlightenment is that members of the public are free, in their capacity as scholars, to debate and discuss any topic they would like with each other. In turn, the third strategy for enlightenment turns on the idea that these free and open debates will "trickle down" into the herd, slowly guiding them to dare to know. Indeed, "[t]his spirit of freedom spreads further... Men work their way by themselves bit by bit out of barbarity if one does not intentionally contrive to hold them in it." 33

However, this third strategy seems like it may collapse into the second one. This is precisely because the sort of critical attitude that such scholarly debates inculcate into the herd may cause the herd to begin to question the hierarchical relationship between themselves and their "betters" as well as the state's coercive use of violence to constitute the public. Indeed, if the public use of reason is unrestricted, it seems like the herd always has the right to challenge and criticize any government policy, order, and so on. Kant himself stresses that

\footnotetext{
${ }^{26}$ E.g., Immanuel Kant, "On the Common Saying: This May be True in Theory, but it Does Not hold In Practice, Parts 2 and 3," in Toward Perpetual Peace and Other Writings on Politics, Peace, and History, ed. P. Kleingeld (New Haven, CT: Yale University Press, 2006), 52-53.

${ }^{27}$ This account for Kant's absolute refusal to accept any "right" to revolution, even against tyranny. See, e.g., ibid., 53. See also Jeremy Waldron, "Kant's Theory of the State," in Toward Perpetual Peace and Other Writings on Politics, Peace, and History, 194-97.

${ }^{28}$ Immanuel Kant, "An Answer to the Question: What is Enlightenment?," in What is Enlightenment? Eighteenth-Century Answers and Twentieth-Century Questions, 59.

${ }^{29}$ Immanuel Kant, Lectures on Logic (Cambridge, UK: Cambridge University Press), 474.

${ }^{30}$ Immanuel Kant, "An Answer to the Question: What is Enlightenment?," 59.

${ }^{31}$ Ibid.

32 Ibid., 60 .

33 Ibid., 62.
} 
such an unbridled use of public reason would "be very destructive" 34 in that it might, e.g., lead an "officer on duty... [to] argue out loud about the suitability... of a command given." 35 Moreover, such unbridled public reasoning might lead a member of the herd to "refuse to pay taxes imposed on him" 36 and such a refusal, if it were to spread among the herd, would bankrupt the state itself. Kant goes so far as to state that such "an impudent complaint against such levies [done in the name of public reason] ... is punished as an outrage (which could lead to general insubordination)." 37

In short, unrestricted use of public reason collapses into revolution and faces the challenges adumbrated above.

To prevent this collapse, Kant contrasts the public use of reason with the private use of reason. The private use of reason is "the use one makes of his reason in a certain civil post or office which is entrusted to him... Here one is certainly not allowed to argue; rather, one must obey." 38 Moreover, Kant stresses that "[h]ere [when one is using one's private reason] one is certainly not allowed to argue; rather, one must obey." ${ }^{39}$ In other words, someone who is not a scholar addressing the public in this role must obey the edicts and decrees of the state. Thus, for Kant, the private use of reason is one that can be appropriately coerced and regulated by the state. Indeed, reflecting on a preacher who has doubts about the teachings of his church, Kant stresses that "the use that an appointed teacher makes of his reason before his congregation is merely a private use because this is only a domestic assembly... in this respect, he is not and cannot be free... because he conforms to the orders of another." 40 In other words, since the doubting preacher is employed by the state as a preacher, he cannot reason publicly in his capacity as a preacher. In effect, since the state pays him for his services, he must obey the state and maintain its orthodoxy- or else resign. ${ }^{41}$ Notice, critically, that, for Kant, there are only two possible positions for such a preacher and, one imagines, any dissident. They can either keep silent in their job or else they can resign. We shall examine what occurs when someone cannot resign as, e.g., they do not have the material resources, more in a moment. Finally, Kant stresses that "[o]nly one ruler in the world says "Argue, as much as you want and about whatever you want, but obey!"' 42

This last sentence, in particular, is critical to making sense of both the distinction between public and private use of reason as well as the proper role of the state in each sphere. The "one ruler" Kant refers to is Fredric the great, he with a well-disciplined military and absolutist inclinations. However, there is something far more critical at work than this historical note. Part of what allows an absolutist regime like Fredric's to foster the public use of reason is precisely that it can sharply distinguish between a public and a private use of reason. If one is told to pay taxes, one must obey. And one must obey precisely because the coercive and centralized power of the absolutist state ensures that one can be compelled. Notice that what evaporates here is any sort of "prejudices." In other words, we have no "prejudices," we trust no authority, we harbor no ideals, and we see that, at this level, political authority does spring from the barrel of a well-disciplined military. In turn, the private use of reason is best thought of as a form of instrumental reasoning wherein the end goal is established and maintained by

\footnotetext{
${ }^{34}$ Ibid., 60 .

35 Ibid.

36 Ibid.

${ }^{37}$ Ibid., emphasis mine.

38 Ibid.

${ }^{39} \mathrm{Ibid}$.

40 Ibid., 61.

${ }^{41}$ Ibid.

${ }^{42}$ Ibid., 59.
} 
the coercive power of the state. In sum, the private use of reason, for Kant, is a "demythologized" and "unprejudiced" understanding of the authority of the state that allows it to posit end goals that I must meet via private reason, or face the penalties. By contrast, the public use of reason emerges from the state's duty to enforce my right to debate freely as a scholar. In other words, the public use of reason depends on the public space that is constituted by the state's ability to enforce openness. Moreover, this openness depends on, e.g., me qua taxpayer supporting the state.

Moreover, Kant further claims that such an absolutist state "can say what a republic cannot dare: argue, as much as you want [publicly]... only obey!"43 The absolutist state can dare to say this for two related reasons. One is that a democracy cannot make such a sharp distinction between public and private uses of reason precisely because I, qua citizen, have a right to fight with the tax collectors. Indeed, in democracies, the state's authority springs from the people and, ergo, the people can insist that the authority is being misused. The other, at once more speculative and far more interesting, is that democracies cannot be "unprejudiced" in the sense Kant insists on. ${ }^{44}$ As has been noted by several thinkers ${ }^{45}$, part of what makes democratic politics works are abstractions that quickly become mythologies. One is made a "citizen" by being inculcated into a "national mythology," one "qua citizen" is "represented" by others, and so on. These cannot survive in the critical vacuum of Kant's pure reason, and so one is left with "the naked truth." I pay my taxes not because I endorse what "my" government does, because I have "pride" in the contingent fact that I was born in one place rather than another, etc., but because they can throw me in jail or have me shot.

With this in view, three questions naturally arise. First, who is the intended audience of the public use of reason? Second, how does one become a scholar and so gain the right to use one's reason publicly? Third, what sort of reasoning should be allowed to take place in the public?

For the first, who is the intended audience, Kant claims that the audience is "the entire commonwealth, indeed even of a cosmopolitan society [of scholars]." 46 Much of the secondary literature has discussed and praised Kant's defense of a grand, international, and egalitarian audience of scholars working together to address critical question without fear of censorship and reprisal. Ergo, so I do not discuss this further. ${ }^{47}$

For the second, how does one become a scholar, Green notes that what is relevant is "not the size of one's audience, but rather... one's employer [and one's gender!]. Reason is used publicly... by the self-employed intellectual." 48 This is very much in keeping with Kant's restriction of citizenship so that " $[t]$ he only quality required for this [i.e., to vote and actively participate in public life], besides the natural one (that it is neither woman nor child) is: that one is one's own master (sui iuris), and that one has some property... that provides for one." 49

43 Ibid., 63.

44 A fascinating discussion in this vein is found in Samuel Fleischacker, Kant's Questions: What is Enlightenment, 46-54

45 E.g., Charles Taylor, "Why Democracy Needs Patriotism," in For The Love of Country?, ed. Joshua Cohen (New York, NY: Beacon Press, 2012), 119-122.

46 Immanuel Kant, "An Answer to the Question: What is Enlightenment?," 60.

47 E.g., Onora O'Neil, "Kant's Conception of Public Reason," in Kant and the Concept of Community ,eds. Charlton Payne \& Lucas Thorpe (Rochester, NY: Rochester Press, 2011), 138-148; Katerina Deligiorgi "Universalizability, Publicity, and Communication: Kant's Conception of Reason," European Journal of Philosophy 10/2 (2002): 143-159.

48 Garrett Green, "Modern Culture Comes of Age: Hamann versus Kant on the Root Metaphor of Enlightenment," in What is Enlightenment? Eighteenth-Century Answers and Twentieth-Century Questions, 296.

${ }^{49}$ Immanuel Kant, "On the Common Saying: This May be True in Theory, but it Does Not hold In Practice, Parts 2 and 3," in Toward Perpetual Peace and Other Writings on Politics, Peace, and History, 49. 
In other words, the people who are entitled to become scholars and so use their public reason are well to do men of leisure. Indeed, the only people who have the luxury of simply resigning a post when their private use reason conflicts with their public conscience are people of some means. For the rest, the majority of people, this is not a "live" option and so, it seems, they cannot be public reasoners at all. Thus, for Kant, to reason publicly is to reason in a disinterested manner, unguided by any features other than one's reason. The epistemic mark of this form of public reasoning is the fact that it can afford to discard any local epistemic or contextual features of a particular person's situation so that other public reasoners can assess its validity. Public reasoning is disinterested or "unprejudiced" reasoning. In turn, any person who is incapable of abstracting "properly" from their local situation is, ipso facto, not publicly reasoning. Thus, people who can be public reasoners are people who have the luxury of abstracting from all sorts of features like, e.g., material needs, epistemic injustices ${ }^{50}$, existential commitments, and so on, and can be guided solely by reason's transcendental light. Anyone who cannot (or will not) do this is part of the lazy and cowardly herd and must obey.

For the third, what sort of reasoning is acceptable in the public, Kant is concerned to limit the "lawlessness in thinking." 51 This lawlessness is a form of "postmodern" thought wherein public reasoning "degenerates" into a form of idiosyncratic intellectual free play. To prevent this, Kant insists that for reasoning to count as public requires that it be universalizable. Given this, Butts argues that part of what ensures that my thinking is universalizable is that

I must have a means for moving from merely private validity to objective validity, which means that I must have a means for moving from features of my internal subjective constraint or disability of character to external features of objects. ${ }^{52}$

Thus, the sort of reasoning that counts as public is precisely the sort that is universal. In turn, this means that the reasoning can be checked by other public reasoners. Notice, critically, that both the other public reasoners and myself must have already adopted a disinterested stance.

In sum, for Kant, our age is an age of enlightenment precisely because there is a strong centralized state that can constitute and enforce a strict separation between the public use of reason and the private use of reason. For the public use of reason, scholars must be free to debate and discuss any topic they would like without reproach or reprisal. Moreover, as the scholarly debates within the public trickle into the herd, we shall gradually move to an enlightened age of grand cosmopolitan scholars debating each other as equals. For the private use of reason, by contrast, the state can justly deploy its coercive powers to set ends for private persons and ensure that these ends are met. Here there can be no debate, but simple obedience to the state, underwritten not by "prejudice" but by force. Also, any person who cannot or will not be a scholar is relegated to this private use.

\section{Noli Admirari! Hamann and the Violence of Universality}

With this account in view, let us turn to Hamann. To begin, Hamann's reply to Kant in Letter to Christian Jacob Kraus, and Hamann's legacy more generally, is complex and contested. Thus,

\footnotetext{
${ }^{50}$ See Miranda Fricker, Epistemic Injustice: Power and the Ethics of Knowing (Oxford, UK: Oxford University Press, 2007), for a powerful discussion of how such a "disinterested" view often masks deeply problematic injustices.

${ }^{51}$ Immanuel Kant, "What does it Mean to Orient Oneself in Thinking," in Religion and Rational Theology (Cambridge, UK: Cambridge University Press, 1996), 17.

${ }^{52}$ Robert E. Butts, “The Grammar of Reason: Hamann's Challenge to Kant," Synthese 75 (1988): 265.
} 
some scholars present Hamann as an arch-irrationalist, someone who attacks the very foundations of reason in order to defend a rather fatuous version of pietism and whose thought always reflects this religious goal. ${ }^{53}$ By contrast, others view him as a radical enlightener whose reply to Kant is nothing so much as a rejection of Kant's tepid moderation and obsequious relationship to authority. ${ }^{54} \mathrm{I}$ stress here that, though these debates are important, I bracket them as far as possible. I also stress that I focus on one theme in Hamann's reply to Kant, to the exclusion of other interdependent strands. To wit, I focus on Hamann's contention that Kant's guardian/unmündigkeit relationship is conceptually unjustified and predicated on violence, not philosophy.

Hamann begins his letter by situating himself. He stresses that "I must take refuge in a macaronic quill." 55 To begin, "macaronic" is defined as "a burlesque form of verse in which vernacular words are introduced into the context of another language." 56 This remark is both performative and philosophically significant. It is performative in that, for the rest of Hamann's essay, he mixes several different languages, sources, citations, and so on, in a purposefully humorous way. It is philosophically important in that Hamann is stressing that he does not consider himself to be part of the guardian class who can shepherd the lazy and cowardly herd. Indeed, in the opening paragraph, and throughout the essay, Hamann aligns himself with the great unwashed masses who Kant thinks need guidance. This is confirmed by the remaining part of the first paragraph wherein Hamann claims that Kant's article, and more importantly, his reply is written in the "cant [common or vulgar] style, which like the comic historian of comic literature has rendered as "Kantian style" per e, like an asmus cum punto." ${ }^{57}$ It is also vital to notice that both Hamann's reference to "e" and his "cum punto" flag the fact that Hebrew orthography does not write vowels. ${ }^{58}$ One plausible reading of this is that Kant's essay is eliding something critical.

To bring out what Kant's essay elides, Hamann notes that "[t]o remind a professor of logic \& critic of pure reason of the rules of definition would be virtual high treason." 59 However, and with some irony, Hamann contends that Kant needs such a reminder. Specifically, Hamann notes that Kant's motto of enlightenment, sapere aude or dare to know, is incomplete in two ways, grammatically speaking. Specifically, "dare to know!" lacks both a grammatical object and leaves the grammatical subject implicit. Let us examine how Hamann fills in these elisions.

First, "dare to Know!" lacks a grammatical object — dare to know what. This point is not trivial. For Kant, a uniform and invariant structure that is a-cultural, trans-historical, nonlocal, and so on, runs across all possible experience and knowledge. Given this, to know anything at all requires that the thing known to conform itself to this structure. Pace this, Hamann stresses that

$[t]$ o the hidden mysteries.... Belongs the possibility of human knowledge of objects without and before any experience and thus the possibility of a sensible intuition before any sensation of object... a chief question [is] how

\footnotetext{
${ }^{53}$ See Isaiah Berlin The Magus of the North: J. G. Hamann and the Origins of Modern Irrationalism (New York, NY: Farrar Strauss \& Giroux, 1994).

${ }^{54}$ See Oswald Bayer, A Contemporary in Dissent: Johann Georg Hamann as Radical Enlightener (Grand Rapids, MI: Erdmans Press, 2012).

55 Johann Georg Hamann, "Letter to Christian Jacob Krauss," 145.

56 Oxford English Dictionary, second definition. Available at: http://www.oed.com/view/ Entry/111764? redirectedFrom=macaronic\#eid (Accessed September 10, 2019).

${ }^{57}$ Johann Georg Hamann, "Letter to Christian Jacob Krauss," 145

58 Ibid., $149 \mathrm{ft} 7$.

59 Ibid., 146.
} 
the faculty of thought is possible... then no deduction is needed to demonstrate the genealogical superiority of language. ${ }^{60}$

In other words, the supposedly purified structure that Kant claims to explore is constituted not by some necessary apperception of perception but by the constitutive function of contingent natural language. ${ }^{61}$ Given this, what we know, and how we do so, is deeply connected with how we talk about it. Indeed, Kant seems to concede this point. Specifically, Kant claims that

[h]e who can only express himself symbolically still has only a few concepts of understanding, and the lively presentation so often admired in the speech presented by the [American] savages.... is nothing but a poverty of concepts and, therefore, also in the words that express them. For example, when the American savage says: "We want to bury the hatchet" and this means: "We want to make peace"... owe their bright eloquence to merely a lack of means for expressing their concepts. ${ }^{62}$

Leaving aside, for the moment, the arrogance of this quote, what is critical is that Kant clearly links together the rarified structure of pure reason with speech. The "savages" lack proper concepts because their language is "impoverished" and "symbolic." In any case, for Hamann, there is no such thing as a disembodied pure reason outside of language. And since language is contingent, culturally dependent, and so on, then so too is the supposedly transcendental light of pure reason Kant claims he, and guardians in general, rely on.

Second, "dare to know!" leaves the grammatical subject unstated. This seems innocuous as most imperative mood sentences do not require the subject be explicitly stated as in, e.g., "[you] close the door!," "[you all] be quiet!" However, Hamann detects here a slight-of-hand on Kant's part. Specifically, is the implicit "you" any reader of Kant's essay, a plural use of the implied second person standing for the general public, or only addressed to guardians? In sum, who is the "you" that Kant's command is intended for?

To address this question of who, Hamann notes that "I can gladly tolerate seeing enlightenment, if not defined, at least elucidated... More aesthetically than dialectically, through the analogy of unmündigkeit and guardianship." 63 In other words, the "who" that should dare to know are those in their unmündigkeit. This is clearly in keeping with Kant's point. However, Hamann then notes that "[e]xcept for me the proton pseudos [root error]... lies in that accursed adjective self-incurred." 64

It is here that the aspect of Hamann's criticism that interests us begins. Recall above that, for Kant, it is critical that the sorry state of unmündigkeit is not due to some inherent limitation but instead due to laziness or cowardice. Thus, "[i]nability is really no fault as our Plato himself recognizes; and it only becomes a fault through the will and its lack of resolution and

\footnotetext{
${ }^{60}$ Johann Georg Hamann, "Metacritique on the Purism of Reason," in What is Enlightenment? EighteenthCentury Answers and Twentieth-Century Questions, ed J. Schmidt (Berkeley, CA: University of California Press, 1996), 154-156.

${ }^{61}$ For insightful discussions on this point, see, e.g., Ian Hacking, "How, Why, When, and Where did Language Go Public," in Historical Ontology (Cambridge, MA: Harvard University Press, 2002), 132-139 and Robert Alan Sparling, Johann Georg Hamann and the Enlightenment Project (Toronto, Canada: University of Toronto Press, 2011), 25-74.

${ }^{62}$ Immanuel Kant, "Anthropology from a Pragmatic Point of View," in Anthropology, History, and Education (Cambridge, UK: Cambridge University Press, 2007), 299.

${ }^{63}$ Johann Georg Hamann, "Letter to Christian Jacob Krauss," 146.

${ }^{64}$ Ibid.
} 
courage." ${ }^{5}$ Notice that Kant's entire discussion of enlightenment turns on this point. The lazy and cowardly masses could obtain enlightenment, if only they would stop being lazy and cowardly. They are culpable precisely because they enjoy their sorry state.

However, how did the lazy and cowardly masses end up in such a position in the first place? Indeed, if Kant is correct that being human, being free, being rational, and being enlightened are tightly interconnected, then what could cause people to falter? Interestingly, Kant is aware of this and claims that "[u]nmündigkeit is the inability to make use of one's own understanding without the guidance of another. Self-Incurred is this inability if its causes lie not in lack of understanding but rather in lack of the resolution and the courage to use it without the guidance of another." 66 Thus, this other, whom the masses rely on to guide them, is the cause of their lack of enlightenment. Unsurprisingly, Hamann asks, "who is the indeterminate other who twice appears anonymously?" 67 Hamann's answer to this question of who the other is that the masses rely on, and so who causes their unmündigkeit is striking. "Answer: the tiresome guardian who must be implicitly understood as the correlate of those who are unmündig [immature]. This is the man of death. The self-incurred guardianship and not unmündigkeit." 68

This passage is critical for three reasons. First, Hamann notes that Kant's entire discussion turns on a binary opposition wherein each correlate conceptually requires the other. In other words, the category of unmündigkeit can only function if one presupposes that there are guardians and vice versa. Legally speaking, this point is quite right. A child is in the guardianship of her caregivers exactly because she is classified as in a state of unmündigkeit, she is in a state of unmündigkeit exactly because some of her rights (and duties) are placed under the care of another, her guardian. Similarly, Kant's claim that some individuals are in their unmündigkeit requires that there are guardians who can shepherd them into a "more enlightened" state and vice versa.

Second, pursuant to this, Hamann stresses that this distinction between guardians and herd is not justified philosophically. Indeed, "[t]he self-incurred unmündigkeit is just such a sneer as he [Kant] makes at the whole fair sex, and which my three daughters will not put up with." ${ }^{69}$ Part of what Hamann is stressing here, in 1784 no less, is that Kant's views on women are absurdly unjustified. Moreover, and leaving this historical note aside, Hamann is raising a far deeper epistemic problem for Kant. Kant has already assumed that, mutatis mutandis, no one should be in a state of unmündigkeit as being human, being rational, being free, and being enlightened are deeply interconnected. However, this means that any distinction between the guardians and the herd cannot be drawn on a principled philosophical ground. As the slogan has it, no distinction without a difference. So since, qua human being, there is no difference between the herd and the guardians, there is no relevant philosophical difference. Given this, Kant's third strategy for enlightenment is wrong. Instead, we should either trust individuals to use their reason now or rise up against our supposed betters.

However, Hamann is aware that such a claim may not satisfy Kant. Though in principle, there are no differences, Kant has stressed that the habits of the herd, and their willful refusal to dare to know, make a distinction between herd and guardian. To this Hamann asks

$[w]$ ith what kind of conscience can a reasoner \& speculator by the stove and in a nightcap accuse the unmündig [immature] ones of cowardice, when their blind guardian has a large, well-disciplined army to guarantee his infallibility

\footnotetext{
${ }^{65}$ Ibid.

${ }^{66}$ Immanuel Kant, "An Answer to the Question: What is Enlightenment?," 58.

${ }^{67}$ Johann Georg Hamann, "Letter to Christian Jacob Krauss,” 146.

${ }^{68} \mathrm{Ibid}$

${ }^{69}$ Ibid., 148.
} 
and orthodoxy? How can one mock the laziness of such unmündig [immature] persons...? ?70

In other words, how can the guardians be so smug when they are the very cause of the herd's unmündigkeit and their "bad" habits?

Moreover, Hamann's question brings several elements into play, two of which are of interest to us. One, Hamann's reference to the nightgown and stove can be plausibly read as alluding to Descartes and modern skepticism. In this, Hamann is pointing out that "dare to know," "doubt everything," and "Noli admirari [wonder at nothing]" are conceptually correlated. Granting this, Hamann then stresses that "[t] he public use of reason \& freedom is nothing but a dessert... The private use is the daily bread that we should give up for its sake." 71 In other words, for Hamann, the grand cosmopolitan conversation wherein pure reason alone guides us, cannot be sustained over the course of the grubby business of life. In this, he is partly following Hume who insists that skepticism vanishes when he begins playing billiards. Similarly, the freedom that Kant seeks to defend vanishes when Hamann, a tax collector and not a scholar ${ }^{72}$, has to go to work and obey his bosses. Two, and more importantly, Hamann is stressing that the unconditioned guidance of reason is, itself, illusory. In effect, Kant simply assumes that disinterested abstraction can "orient itself in thinking." "73 Pace this, Hamann notes that "the only, first, and last, organon and criterion of reason... [is] tradition and usage." 74 One powerful way to understand this claim is through later Wittgenstein. For example, later Wittgenstein argues that even a basic rule like " $2(\mathrm{x})$," can, when isolated from practices, education, culture, language, and so on, be interpreted to warrant any action at all. There are no rails to infinity, no mystical force of pure reason that compels me to view the series " $2,4,6$ " as correct and " $2,4,9$ " as wrong, no clarity so pure that a rule can self-predicate its "correct" interpretation into my head. ${ }^{75}$ There are practices, trainings, teachings, cultures, traditions. Without this, we are in a vacuum. In turn, this makes the sort of disinterested abstraction Kant valorizes a mere illusion as reason cannot, of its own accord, lead us anywhere at all. This problematizes the claim that some select few guardians can rely on only their reason in the first place and that this reliance makes the difference Kant needs. Moreover, clearly in a more practical form, this objection also presages the charge of empty formalism against Kant. ${ }^{76}$ In effect, Hamann points out that Kant's pure practical reason, by insisting on universalization, either empties any maxim for action to the point where it offers no check on any behavior or else Kant smuggles in content by, e.g., assuming private property (a contingent feature of the social world) to demonstrate that theft is self-contradictory.

Third, Hamann's most crucial criticism follows from the first and second point. Given both that Kant's unmündigkeit/guardian distinction is a binary and given that it cannot be justified philosophically, it must be justified politically. Thus, Hamann notes that the "distinction between the public and private service of reason... [unifies] the two natures of

\footnotetext{
${ }^{70}$ Ibid., 147.

${ }^{71}$ Ibid., 148.

${ }^{72}$ For a brief and helpful biography of Hamann, see Robert Alan Sparling, Johann Georg Hamann and the Enlightenment Project, 13-24.

73 See Immanuel Kant, "What does it Mean to Orient Oneself in Thinking," in Religion and Rational Theology (Cambridge, UK: Cambridge University Press, 1996), 7-18.

${ }^{74}$ Johann Georg Hamann, "Metacritique on the Purism of Reason," 155.

${ }^{75}$ See Ludwig Wittgenstein, Pbilosophical Investigations (Oxford, UK: Wiley-Blackwell Press, 2009), sec. 201. For a powerful, though problematic, elaboration, see Saul Kripke, Wittgenstein on Rules and Private Language (Cambridge, MA: Harvard University Press, 1982), 7-54.

${ }^{76}$ See Charles Taylor, Hegel (Cambridge, UK: Cambridge University Press, 1975), 371.
} 
an unmündig [immature] \& a guardian, by making both into self-contradictory hypocrites... here lies precisely the nub of the whole political problem." 77 Furthermore, Hamann stresses that Kant's view is hypocritical exactly because Kant "reckons himself to the class of guardians and wishes thereby to attain a high reputation before unmündig [immature] readers." 78 Indeed, for Hamman, the entire reason that the herd seems to be in a sorry state of unmündigkeit is caused by Kant's arrogant condescension towards them. Thus,

[t]he unmündigkeit is thus self-incurred only insofar as it surrenders to the guidance of a blind or invisible... guardian or leader... So wherein lies the inability or fault of the falsely accused immature one? In his own laziness and cowardice? No, it lies in the blindness of his guardian. ${ }^{79}$

In other words, the herd seems so lazy or cowardly to Kant exactly because he takes himself to be outside and above it. Moreover, this unjustified hubris engenders at least three disturbing political ramifications.

One, it causes the guardians to delude themselves and celebrate a form of "freedom" that is utterly disconnected from any reality. Indeed, Hamann stresses that Kant's "freedom" requires that one "must forget everything \& contradict everything as soon as, in their own self-incurred unmündigkeit, they [the guardians] are to do indentured labor for the state." 80 In other words, Kant's freedom vanishes the second the scholars leave Laputa and have to try to make a living, as noted above. Moreover, and worse, this "freedom" presupposes that reason is a self-guiding entity, a point Hamann has already denied. Thus, for Hamann, the lionization of public reason among the guardian class is little more than "a mere northern light, from which can be prophesied no cosmopolitical chiliasm except in a nightcap \& by the stove." 81 It is, then, no wonder that Fredric and the state more generally have nothing to fear from the sound and fury of scholars who forget everything except the blinding light of transcendental reasoning and discuss everything so long as it is so emptied of content as to have no connection with anything else.

Two, this hubris causes the guardians to portray the masses appallingly. Specifically, Hamann claims that the guardians view those who are supposedly in their unmündigkeit as "not even machines but mere shadows of his [the guardian's] grandeur, of which he [the guardian] need have no fear at all, since they are his ministering spirits and the only ones whose existence he believes? So doesn't it all come to the same thing? - believe march, pay, if the d[evil] is not to take you." 82 Hamann is here making two interconnected points. First, since the private use of reason is based on the coercive power of the state, anyone who cannot or will not join the public reasoners is relegated to a form of near slavery to the state. Indeed, "[w] hat good to me is the festive garment of freedom when I am in a slave's smock at home?" 83 Second, and far worse, what underwrites this is a profoundly troubling misfire at the heart of Kant's ethics. To see this, let us follow Taylor who notes that, for Kant, freedom is "acting according to what we truly are, moral/rational agents... It [the law of morality that should guide our actions] is dictated by the very nature of reason itself. To be a rational agent is to act for reasons. By their very nature, reasons are of general application." ${ }^{84}$ Given this, and given the

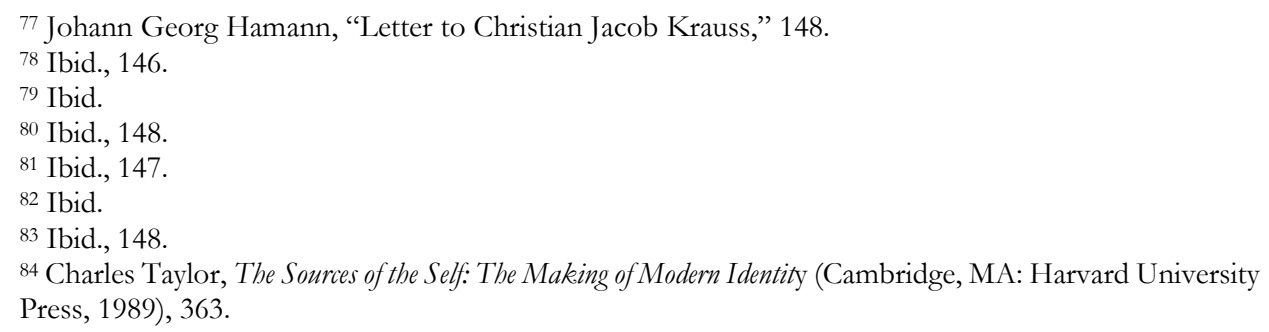


link between universality and public reason, it follows that anyone who cannot or will not be a public reasoner does not count as a moral/rational agent. In turn, this exclusion renders these beings non-moral and so the guardians are entirely justified in moving them about in any way they see fit. Indeed, they are less than machines in that, as yet, they are mere raw materials for the guardians to transform into whatever they see fit. And they are ministering spirits in that they, the raw materials, merely reflect the glory of the guardians. Indeed, recall Kant's somewhat ungrounded and arrogant claim that American "savages" lack proper concepts as their language is "symbolic." Given this, one can easily imagine sliding from this (dubious!) empirical note to the claim that the "savages" lack reason and so are not, properly speaking, moral agents at all. This train of thought may seem unfair to Kant. ${ }^{85}$ We return to this briefly in section three. Regardless, notice that Hamann can be read as making a subtle joke with a horrifying point. The joke is that much as for Kant, the un-schematized "input" is a vanishing point, a something $=\mathrm{X}$, so too are those in their unmündigkeit mere vanishing points, beings without rationality, freedom, or a will of their own, to be shaped as the guardian sees fit. The horrifying point is that this annihilates any basis for respecting them at all.

Three, related to one and two, Hamann points out that what underwrites Kant's hubristic arrogance as well as the sharp distinction between public and private, is the violence of the state. Indeed, the entire distinction turns on the fact that the unwashed masses can be compelled by the state to privately reason towards state ends and, when not so forced, these masses should listen in rapture to the grand conversation of mankind as it unfolds between men of leisure. Needless to say, what such an absurd view elides is precisely the real injustices, struggles, pain and suffering, and so on, that state violence inflicts on those "raw materials" whom Kant has the audacity to condemn as lazy cowards. Thus, Hamann twice calls Kant, the representative of the self-appointed guardians, "the man of death." 86 Such a claim might seem hyperbolic. However, as we shall see in section three, it is anything but as the postcolonial record shows. Regardless, the conceptual underpinnings for Hamann's claim partly relate to the "de-mystification" that Kant's enlightenment brings with it. The reason someone should pay her taxes is not that she identifies with her fellow citizens, because she feels that the use of taxes is justified for the community's good, and so on. Instead, she pays her taxes because the state can shoot her if she does not. In this, Hamann is merely carrying a theme of Kant's to its logical conclusion. A well-armed military is a precondition for enlightenment exactly because it can establish, maintain, and enforce, the boundaries between public and private reason. Without this, the distinction collapses and enlightenment becomes impossible.

Thus, the grand conversation of cosmopolitan scholars that constitute the public use of reasoning is a mere farce. Guardian/herd, public reason/private reason, and universal/ cultural are all interdependent with each other. Moreover, these distinctions are not justified on some transcendental grounds but reflect the guardians' self-assured arrogance and their hatred of the herd. Indeed, what establishes and maintains the distinctions at issue are not philosophical nuances, but well-disciplined militaries that can ensure that taxes are paid. In sum, for Hamann, the enlightenment as Kant understands it is nothing more than "prattle and reasoning of the emancipated unmündig [immature] ones... [who are backed by] couteaux de chasse [a kind of hunting knife Fredric the great was fond of] and daggers- all this is a cold, unfruitful moonlight without the warmth for the cowardly will." 87

\footnotetext{
85 Though see, e.g., Hilary Putnam, Jewish Philosophy as a Guide to Life (Bloomington, IN: Indiana University Press, 2008), 70-72, for a brief but powerful reconstruction of Levinas's claim that Kant's ethics opens the door to death camps as any $\mathrm{x}$ that is not considered human/rational falls outside moral considerations.

${ }^{86}$ Johann Georg Hamann, "Letter to Christian Jacob Krauss," 146

87 Ibid., 148.
} 
With this in view, finally, let us see if Hamann's criticism is borne out empirically. In other words, does Hamann's trenchant attack on the guardian/herd distinction and his contention that violence, not philosophy, underwrites it, have any empirical support. As we shall see, sadly, it does.

\section{Hamann, Our Post-Colonial Contemporary}

With all this in view, we can see that Hamann's critique of threads of Kant's conception of Enlightenment is undoubtedly exciting and prima facie coherent. However, the reader might be skeptical about how realistic and helpful his critique is. Indeed, given the tenor of the time, the reader might argue that the masses have shown themselves to be too ignorant to be trusted and that Kant's third strategy is the best way to ensure the stable and prosperous world in which we, in "the West," live. 88 To answer this skepticism, I want to align Hamann's fears with post-colonial realities. In effect, I hope to show that not only is Hamann's critique coherent but, sadly, that it identified many of the darker aspects of the so-called Enlightenment that are glaringly obvious when we leave Laputa. Specifically, I focus on connecting four themes in Hamann's critique to direct correlates in post-colonial thought. To make this point as powerfully as I can, I focus on what many consider the shinning achievement of Kant's Enlightenment- a world order committed to human rights. Specifically, I follow many post-colonial thinkers in arguing that, though human rights ideals are laudable, many deeply troubling features occur during their implementation.

The first theme I discuss is Hamann's contention that the asymmetry between the guardians and the herd is unjustified and arrogant. To begin, Mutua tellingly notes that the implementation of human rights is marked "by a damning metaphor [recall Hamann's charge against Kant's definition]. The grand narrative of human rights contains a subtext that depicts an epochal contest pitting savages, on the one hand, against victims and saviors, on the other." 89 Commenting on the "savior" part of the metaphor, Mutau notes that it is "constructed through two intertwining characteristics Eurocentric universalism and Christianity's missionary zeal.... the savior metaphor is deeply embedded in the Enlightenment's universalist pretensions, which constructed Europe as superior and as the center of the universe." 90 Notice that this point and Hamann's arguments against a transcendental vantage point Kant claims to adopt, align perfectly. In both cases, an unjustified claim to universality is made. Matau also stresses that these "saviors" are the "saviors" of "freedom: freedom from the tyrannies of the state, tradition, and culture. But it is also the freedom to create a better society based on particular values... a set of culturally based norms and practices that inhere in liberal thought and philosophy." 91 In turn, one danger of this "savior"-complex, as Hamann noted and as Matua stresses, is that it recasts the unwashed masses as "weak, powerless, prone to laziness, and unable to create the conditions for his development was a recurrent theme in Western representations of the "other."... In the culture of the human rights movement, whose center is in the West, there is a belief that

${ }^{88}$ For example, Jason Stanley, How Fascism Works: The Politics of Us and Them (New York, NY: Random House, 2018), 113-119, comes rather close to arguing that, since the masses are too lazy or unenlightened to distinguish conspiracy theories from real news, the government should take active measures to limit the former.

89 Makau W Mutua, "Savages, Victims, and Saviors: The Metaphor of Human Rights," Harvard International Law Journal 42/1 (2001): 201.

${ }^{90}$ Ibid., 233. See also, Ratna Kapur, "The Tragedy of Victimization Rhetoric: Resurrecting the "Native" Subject in International/Post-Colonial Feminist Legal Politics," Harvard Human Rights Journal 15 (2002): $1-37$.

${ }^{91}$ Makau W Mutua, “Savages, Victims, and Saviors: The Metaphor of Human Rights”: 204 
human rights problems affect people "over there" and not people "like us." The missionary zeal to help those who cannot help themselves is one of the logical conclusions of this attitude." 92 Thus, the asymmetry that inflects much of human rights discourse is predicated on a spurious claim to universality and an arrogant contention that the other is too lazy, uneducated, or cowardly to help herself. ${ }^{93}$

Granting this, the second theme is that the guardian/masses or savior/victim, metaphor presupposes and predicates violence. It presupposes violence, as it both requires that there be masses/victims to enlighten/save and holds in abeyance the material and economic realities of the masses/victims. Thus, Asad notes that

[t]he first part of Article 25 of The Universal Declaration of Human Rights states that "everyone has the right to a standard of living adequate... [to] himself and his family..." But the responsibility for ensuring the conditions in which these rights can be realized is assigned solely to individual sovereign states... Damage done to the economy of another country... does not constitute a violation of human rights. ${ }^{94}$

Again, Hamann's charge that Kant refuses to deal with the concrete realities rings true. By ignoring the real on-the-ground economic depravity, human rights discourse occludes a powerful source of injustice and focuses instead on, e.g., cultural issues. It predicates violence as many guardians/saviors seek to "rescue them [women or victims] from their culture," 95 sometimes even advocating military interventions that usually make matters far worse. For example, in 2001, much "Western" liberal and human rights discourse cast Afghanistan as a "primitive" or "medieval society" that we needed to free from its torpor. ${ }^{96}$ Indeed, we in the "West" needed to be "guardians" and to lead these poor people from darkness into light. Of course, what such an account occludes is the role the "West" played, via military interventions, unfair international relations, and so on, in transforming a moderate kingdom into a nightmarish hellscape. ${ }^{97}$ Moreover, as of writing this essay, the war "for liberation" in Afghanistan is about 20 years old and shows no signs of stopping. The man of death, indeed. ${ }^{98}$

The third theme that Hamann emphasizes is that talk of rights and public reason require some state that bears the duty to enforce these rights. Indeed, as noted in section one, the state not only bears such a duty, but it is an apodotic posit of pure practical reason that the state does whatever is necessary to enforce these rights. Moreover, according to Hamann, for the state to fulfill this duty requires that it centralizes authority by disrupting and replacing local and historical ways of living together as well as "rationalizing," often quite violently, the

\footnotetext{
${ }^{92}$ Ibid., 232.

${ }^{93}$ Though he considers himself a defender of the enlightenment, Easterly gives example after of example of how technocratic development policy experts who "know best" have inflicted untold suffering on the "developing" world through their guardianship. See William Easterly, The Tyranny of Experts: Economists, Dictators, and the Forgotten Rights of the Poor (New York, NY: Basic Books, 2013).

94 Talal Asad, Formations of the Secular: Christianity, Islam Modernity (Stanford, CA: Stanford University Press, 2003), 128-129.

${ }^{95}$ Lila Abu-Lughod, Do Muslim Women Need Saving? (Cambridge, MA: Harvard University Press, 2013), 6-7

96 See Charles Hirschkind \& Saba Mahmood, "Feminism, the Taliban, and the Politics of CounterInsurgency," Anthropology Quarterly Vol 75(2): 339-354.

${ }^{97}$ See, for instance, Steve Coll, Ghost Wars: The Secret History of the CLA, Afghanistan, and Bin Laden from the Soviet Invasion to September 10, 2001 (New York, NY: Penguin Press, 2004).

98 Sadly, such examples can be easily multiplied. See, e.g., Noam Chomsky, Hegemony or Survival: American's Quest for Global Domination (New York, NY: Metropolitan Books, 2003), for a sobering set of cases.
} 
culture in question so that the state can more easily enforce rights. ${ }^{99}$ Each of these finds a direct correlate in post-colonial theory. The claim that states, under the auspices of rights talk, centralize authority and disrupts established ways of living together is emphasized by several thinkers. ${ }^{100}$ Moreover, this displacement of local norms often renders individuals more and more dependent on the state as their local ways of doing things become increasingly marginalized. In this key, tellingly, Hamann's analysis seems exactly right- it is the state's centralized authority, its imposition of rights, and its displacement of long-standing practices, that renders individuals unmündig [immature]. The role of the state in "rationalizing" a local culture so that it is "legible" and laws can be enforced is powerfully discussed by Scott. ${ }^{101}$ Scott notes that the state's will-to-simplify and standardize often "create [a new social reality]... through its ability to give its [simplifying] categories the force of law." 102 In turn, such "rationalization" further displaces local ways of doing things and often simply silences the concerns of the people who are forced to speak in only the language of rights. ${ }^{103}$ And, finally, the fact that the duty of the state is a universal and apodictic mandate from pure practical reason gives the state a justification for its actions, regardless of what people may want or think.

Fourth, and finally, both Hamann and post-colonial theorists are deeply skeptical of the bounds Kant sets for acceptable public reasoning. For Kant, the keys to entering the free garden of public reasoning are universality and disinterest. Against universality, Asad notes that "[ $t]$ he ideology of political representation in liberal democracies makes it difficult if not impossible to represent Muslims as Muslims. Why? Because in theory, the citizens who constitute a democratic state belong to a class that is defined only by what is common to all its members." 104 As Asad goes on to argue, what is lost in this shift to universality is precisely the religious and existential commitments of the individuals in question. Thus, the desire of a devout Catholic to wear a cross, a Muslim woman to cover her hair, and so on, are all relegated to the realm of mere "private" concerns. Moreover, this loss means that the sort of recognition that the person desires is ruled out of bounds at the outset. And part of what Asad, among others, stresses is that the price of admission to the garden of public reason might simply be too high to pay. Everything that makes a person who she is, as opposed to a game-theoretic agent behind a veil of ignorance ${ }^{105}$, is stripped completely. ${ }^{106}$ Against disinterest, both Hamann and post-colonial theorists are deeply skeptical that such a stance is even possible. For both, one is always already a situated thinker within a particular culture, against a particular historical situation, and so on. To pretend otherwise is to adopt an ersatz

99 As ever, Hamann makes these points humorously by, e.g., mocking proposed language reforms to German. However, as always, his points are deadly serious. See Johann Georg Hamann, "New Apology for the Letter H," in Hamann: Writings on Philosophy and Language (Cambridge, UK: Cambridge University Press, 2007).

100 See David Kenny, "The International Human Rights Movement: Part of the Problem?," Harvard Human Rights Journal 101 (2002): 123-25. See also Ratna Kapur, "The Tragedy of Victimization Rhetoric: Resurrecting the "Native" Subject in International/Post-Colonial Feminist Legal Politics": 17-27.

101 James C. Scott, Seeing Like a State (New Haven, CT: Yale University Press, 1998).

102 Ibid., 3.

103 See Gayatri Chakravorty Spivak, "Can the Subaltern Speak?," in Colonial Discourse and Post Colonial Theory, eds P. Williams and L. Chrisman (New York, NY: Columbia University Press, 1994), 66-111, for the groundwork for this way of thinking.

104 Talal Asad, Formations of the Secular: Christianity, Islam Modernity, 173.

105 See John Rawls, A Theory of Justice, 118-130.

106 Obviously, this post-colonial charge aligns with communitarian criticisms of liberal justice. See, for instance, Michael Sandel, Liberalism and the Limits of Justice (Cambridge, UK: Cambridge University Press, 1998). 
view from nowhere that silences the genuine concerns and struggles of real people. Moreover, and worse, such a position transmutes a historical person's reasons into Reason, her mores into Ethics, and so on. Needless to say, this transmutation is deeply entwinned with the construction of the civilized self and the barbarous other, constantly in a state of unmündigkeit. The consequence of this view is epitomized in the following:

Take up the White Man's burden [or the human rights advocate's burden or the public reasoner's burden] -

Send forth the best ye breed

Go bind your sons to exile

To serve your captives' [i.e., those who are in a state of unmündigkeit] need. ${ }^{107}$

\section{Conclusion}

Thus, we see that there is an unstable and violent asymmetry at the heart of Kant's third strategy for Enlightenment. We also see that Hamann detected this, foresaw the consequences, and attacked it as best he could. And we finally see that the track record of the subsequent Enlightenment, even in its most noble form, tends to justify Hamann's worries.

I close by noting that this essay is not an attack on either reasoning discussions, the hope that these can spread and resolve many seemingly intractable problems, and the noble ideals of human rights. Instead, it is an attack on Kant's Platonic conception of philosophers as enlightened guardians, slowly leading the ignorant masses into the truth. In place of this conception of Enlightenment, and as Hamann himself stressed ${ }^{108}$, the philosopher's role should be Socratic- predicated on acknowledged ignorance and eschewing all claims to power, authority, influence, and so on. Back to the marketplaces! Back to the lessons of bricklayers and tax collectors!

\section{Acknowledgements}

I would like to thank the reviewers for their helpful comments and suggestions.

\section{References}

Abu-Lughod, Lila. Do Muslim Women Need Saving? Cambridge, MA: Harvard University Press, 2003

Asad, Talal. Formations of the Secular: Christianity, Islam Modernity. Sandford, CA: Stanford University Press, 2003

Bayer, Oswald. A Contemporary in Dissent: Johann Georg Hamann as Radical Enlightener. Grand Rapids, MI: Erdmans Press, 2012.

Berlin, Isaiah. The Magus of the North: J. G. Hamann and the Origins of Modern Irrationalism. New York, NY: Farrar Strauss \& Giroux, 1994.

Butts, Robert E. “The Grammar of Reason: Hamann's Challenge to Kant.” Synthese 75 (1988): 251-283.

107 Rudyard Kipling, “Take Up the White Man's Burden" Available at: https://www.bartleby.com/364/169.html (Accessed September 12, 2019).

108 Johann Georg Hamann, Hamann's Socratic Memorabilia: A Translation and Commentary (Baltimore, MR: John Hopkins University Press, 1967). 
Chomsky, Noam. Hegemony or Survival: American's Quest for Global Domination. New York, NY: Metropolitan Books, 2003.

Coll, Steve. Ghost Wars: The Secret History of the CLA, Afghanistan, and Bin Laden from the Soviet Invasion to September 10, 2001. New York, NY: Penguin Press, 2004.

Deligiorgi, Katerina. "Universalizability, Publicity, and Communication: Kant's Conception of Reason" European Journal of Philosophy 10/2 (2002): 143-159.

Easterly, William. The Tyranny of Experts: Economists, Dictators, and the Forgotten Rights of the Poor. New York, NY: Basic Books, 2013

Fleischacker, Samuel. Kant's Questions: What is Enlightenment. New York, NY: Routledge Press, 2013

Fricker, Miranda. Epistemic Injustice: Power and the Ethics of Knowing. Oxford, UK: Oxford University Press, 2007.

Green, Garrett. "Modern Culture Comes of Age: Hamann versus Kant on the Root Metaphor of

Enlightenment." In What is Enlightenment? Eighteenth-Century Answers and Twentieth-Century Questions, edited by James Schmidt. Berkeley, CA: University of California Press, 1996.

Hacking, Ian. "How, Why, When, and Where did Language Go Public." In Historical Ontology. Cambridge, MA: University Press, 2002.

Hamann, Johann Georg. Hamann's Socratic Memorabilia: A Translation and Commentary. Baltimore, MR: John Hopkins University Press, 1967 . "Letter to Christian Jacob Krauss." In What is Enlightenment? Eighteenth-Century Answers and Twentieth-Century Questions. Edited by James Schmidt. Berkeley, CA: University of California Press, 1996. "Metacritique on the Purism of Reason." In What is Enlightenment? Eighteenth-Century Answers and Twentieth-Century Questions. Edited by James Schmidt. Berkeley, CA: University of California Press, 1996 "New Apology for the Letter H." In Hamann: Writings on Pbilosophy and Language. Cambridge, UK: University Press, 2007.

Hirschkind, Charles \& Mahmood, Saba. "Feminism, the Taliban, and the Politics of Counter-Insurgency." Anthropology Quarterly Vol 75(2): 339-354.

Kant, Immanuel. "An Answer to the Question: What is Enlightenment?" In What is Enlightenment? Eighteenth-Century Answers and Twentieth-Century Questions. Edited by James Schmidt. Berkeley, CA: University of California Press, 1996. . "On the Supposed Right to Lie for Philanthropy." In Kant's Practical Philosophy. Cambridge, UK: Cambridge University Press, 1996. . "What does it Mean to Orient Oneself in Thinking." In Religion and Rational Theology. Cambridge, UK: Cambridge University Press, 1996. Groundwork of the Metaphysics of Morals. New Haven, CT: Yale University Press, 2002. Lectures on Logic. Cambridge, UK: Cambridge University Press, 2002. Toward Perpetual Peace and Other Writings on Politics, Peace, and History. Edited by Pauline Kleingeld. New Haven, CT Yale University Press Press, 2006. "Anthropology from a Pragmatic Point of View." In Anthropology, History, and Education. Cambridge, UK: Cambridge University Press, 2007.

Kapur, Ratna. "The Tragedy of Victimization Rhetoric: Resurrecting the "Native" Subject in International/Post-Colonial Feminist Legal Politics." Harvard Human Rights Journal 15 (2002): 1-37.

Kenny, David William. "The International Human Rights Movement: Part of the Problem?" Harvard Human Rights Journal 101 (2002).

Kipling, Rudyard. “Take Up the White Man's Burden" Available at: https://www.bartleby.com/364/169.html. Accessed September 12, 2019. 
Kripke, Saul. Wittgenstein on Rules and Private Language. Cambridge, MA: Harvard University Press, 1982

Laursen, John Christian. "The Subversive Kant: The Vocabulary of "Public" and "Publicity"." In What is Enlightenment? Eighteenth-Century Answers and Twentieth-Century Questions, edited by James Schmidt. Berkeley, CA: University of California Press, 1996.

Louden, Robert. “Argue but Obey? Questioning Kant's Enlightenment.” In Kant's Shorter Writings: Critical Paths Outside the Critiques, edited by Rafael V. Orden Jiménez, Robert Hanna, Robert Louden, Jacinto Rivera de Rosales, and Nuria Sánchez Madrid. Cambridge, UK: Cambridge Scholars Publishing, 2016.

Mutua, Makau W. "Savages, Victims, and Saviors: The Metaphor of Human Rights." Harvard International Law Journal 42/1 (2001): 201-245

O'Neil, Onora. "Kant's Conception of Public Reason." In Kant and the Concept of Community, edited by Charlton Payne \& Lucas Thorpe. Rochester, NY: Rochester Press, 2011.

Oxford English Dictionary. Available at: https://www.oed.com.

Putnam, Hilary. Jewish Philosophy as a Guide to Life. Bloomington, IN: Indiana University Press, 2008.

Rawls, John. A Theory of Justice. Cambridge, MA: Belknap Press, 1999

Sandel, Michael. Liberalism and the Limits of Justice. Cambridge, UK: Cambridge University Press, 1988.

Scott, James C. Seeing Like a State. New Haven, CT: Yale University Press,1998.

Sparling, Robert Alan. Johann Georg Hamann and the Enlightenment Project. Toronto, Canada: University of Toronto Press, 2011.

Spivak, Gayatri Chakravorty. "Can the Subaltern Speak?” Colonial Discourse and Post-Colonial Theory, edited by Patrick Williams and Laura Chrisman. New York, NY: Columbia University Press, 1994.

Stanley, Jason. How Fascism Works: The Politics of Us and Them. New York, NY: Random House, 2018.

Taylor, Charles. Hegel. Cambridge, UK: Cambridge University Press, 1975. The Sources of the Self: The Making of Modern Identity. Cambridge, MA: Harvard University Press, 1989. . "Why Democracy Needs Patriotism." In For The Love of Country?, ed J. Cohen New York, NY: Beacon Press, 2006.

Taylor, Robert S. "Democratic Transitions and Progress of Absolutism in Kant's Political thought." The Journal of Politics 68/3 (2006): 556-558.

Waldron, Jeremy. "Kant's Theory of the State." In Toward Perpetual Peace and Other Writings on Politics, Peace, and History, edited by Pauline Kleingeld. New Haven, CT: Yale University Press, 2006.

Wittgenstein, Ludwig. Philosophical Investigations. Oxford, UK: Wiley-Blackwell Press, 2009.

Zedler, Johann Heinrich. Vollständiges Universal-Lexikon 1754. Available at: https:/ / www.zedler-lexikon.de/index.html?c=blaettern\&id=265705

\&bandnummer $=29 \&$ seitenzahl $=0577 \&$ supplement $=0 \&$ dateiformat $=1$. Accessed 20 September, 2019. 